\section{ADSORPTION OF MALACHITE GREEN DYE USING SPENT COFFEE GROUND BIOCHAR: OPTIMISATION USING RESPONSE SURFACE METHODOLOGY}

Mardawani Mohamada*, Rizki Wannaharia, Rosmawani Mohammada, Noor Fazliani Shoparwea, Ahmad Saufi Mohd Nawib, Kwan Wei Lunb, Lim Jun Weic,d

aFaculty of Bioengineering and Technology, Universiti Malaysia Kelantan, Jeli Campus, 17600 Jeli, Kelantan, Malaysia bFaculty of Agro-Based Industry, Universiti Malaysia Kelantan, Jeli Campus, 17600 Jeli, Kelantan, Malaysia cDepartment of Fundamental and Applied Sciences, Universiti Teknologi PETRONAS, 32610 Seri Iskandar, Perak Darul Ridzuan, Malaysia ¿Centre for Biofuel and Biochemical Research, Institute of SelfSustainable Building, Universiti Teknologi PETRONAS, 32610 Seri Iskandar, Perak Darul Ridzuan, Malaysia
Article history

Received

20 April 2020

Received in revised form

24 October 2020

Accepted

4 November 2020

Published online

17 December 2020

*Corresponding author mardawani.m@umk.edu.my

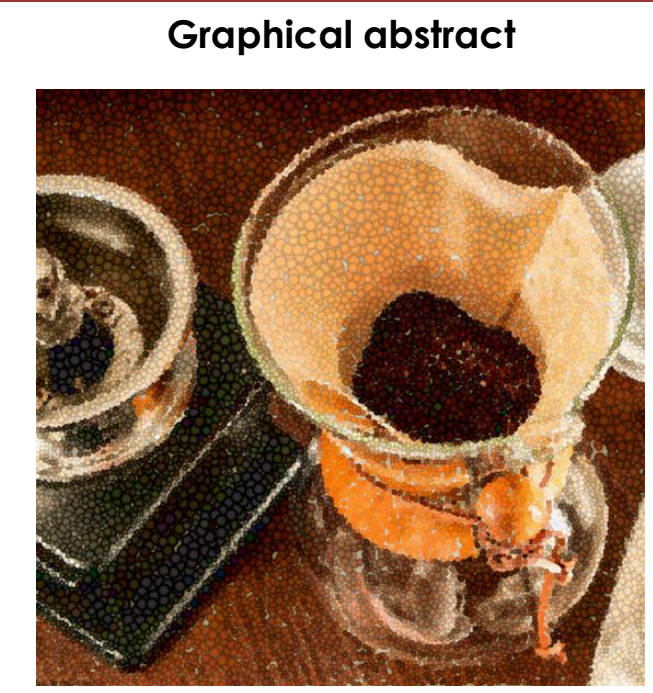

\begin{abstract}
Used coffee grounds usually end up as landfill. However, the unique structural properties of its porous surface make coffee grounds can be transformed into biochar and performed as an alternative low cost adsorbent. Malachite green (MG) is a readily water soluble dye which is used extensively in textile and aquaculture industries. The mordant complex structures of MG generate destructive effects to animals and environment. In this study, adsorption of malachite green using spent coffee ground biochar as adsorbent was investigated. The experiments were designed in two methods: classical and optimisation by response surface methodology. Three parameters were studied, which are adsorbent dosage, contact time and $\mathrm{pH}$ while the responses in this study are malachite green removal (\%) and adsorption capacity $(\mathrm{mg} / \mathrm{g})$. Optimisation studies were performed using response surface methodology. Quadratic model was chosen for both response and studied using central composite design. The correlation coefficient, $\mathrm{R}^{2}$ for the quadratic model of malachite green removal (\%) and adsorption capacity (mg/g) were 0.95 and 0.99 , respectively. The optimum malachite green removal (\%) predicted was found at $99.27 \%$, by using $0.12 \mathrm{~g}$ of adsorbent dosage, 43.05 minutes of contact time and $\mathrm{pH}$ of 9.45 at desirability of 1.0 . The optimum adsorption capacity $(\mathrm{mg} / \mathrm{g})$ predicted was found at $118.01 \mathrm{mg} / \mathrm{g}$, by using $0.02 \mathrm{~g}$ of adsorbent dosage, 60 minutes of contact time and $\mathrm{pH}$ of 10.24 at desirability of 0.98 . So, it was concluded that the spent coffee ground biochar can be used as an effective adsorbent for malachite green removal from aqueous solution.
\end{abstract}

Keywords: Spent coffee ground, biochar, adsorption, malachite green, response surface methodology 


\begin{abstract}
Abstrak
Serbuk kopi terpakai biasanya dibuang di tempat pembuangan sampah. Walau bagaimanapun, sifat struktur permukaannya yang berpori dan unik menjadikan serbuk kopi terpakai boleh diubah menjadi bioarang dan dijadikan sebagai bahan penjerap alternatif berkos rendah. Malekit hijau (MG) adalah pewarna yang larut dalam air serta banyak digunakan dalam industri tekstil dan akuakultur. Struktur kompleks MG yang terhasil akan memberi kesan kerosakan kepada haiwan dan persekitaran. Dalam kajian ini, penjerapan pewarna malekit hijau menggunakan bioarang serbuk kopi sebagai bahan penjerap telah disiasat. Eksperimen telah direka bentuk dalam dua kaedah: klasik dan pengoptimuman dengan metodologi respons permukaan. Tiga parameter telah dikaji, iaitu dos bahan penjerap, masa sentuhan dan $\mathrm{pH}$ manakala respon dalam kajian ini adalah penyingkiran malekit hijau (\%) dan kapasiti penjerapan (mg/g). Kajian pengoptimuman telah dilaksanakan dengan menggunakan metodologi respons permukaan. Model kuadratik telah dipilih untuk kedua-dua respon dan dikaji menggunakan reka bentuk komposit berpusat. Pekali korelasi, $\mathrm{R}^{2}$ untuk model kuadratik bagi penyingkiran malekit hijau (\%) dan kapasiti penjerapan (mg/g) masing-masing adalah 0.9506 dan 0.9935 . Penyingkiran malekit hijau yang optimum (\%) adalah didapati pada $99.27 \%$, dengan menggunakan $0.12 \mathrm{~g}$ dos bahan penjerap, 43.05 minit masa sentuhan dan $\mathrm{pH} 9.45$ pada kebolehinginan 1.0. Kapasiti penjerapan optimum $(\mathrm{mg} / \mathrm{g})$ yang diramalkan didapati pada $118.01 \mathrm{mg} / \mathrm{g}$, dengan menggunakan $0.02 \mathrm{~g}$ dos bahan penjerap, 60 minit masa sentuhan dan pH 10.24 pada kebolehinginan 0.98 . Oleh itu, dapat disimpulkan bahawa bioarang serbuk kopi boleh digunakan sebagai bahan penjerap yang efektif untuk penyingkiran malekit hijau daripada larutan akueus.

Kata kunci: Serbuk kopi, bioarang, penjerapan, malekit hijau, metodologi respons permukaan

(C) 2021 Penerbit UTM Press. All rights reserved
\end{abstract}

\subsection{INTRODUCTION}

Malachite green (MG) dye is extensively used in various industries such as textile, plastic and paper printing. However, usage and disposal of MG has become a controversial issue due to its carcinogenic properties which poses high risk to the environment, ecosystem and human health problems [1]. MG has a chemical formula of $\mathrm{C}_{23} \mathrm{H}_{25} \mathrm{~N}_{2} \mathrm{Cl}$ and it can exist in two major formed after undergo chemical reaction with others compound, which are leucomalachite green and malachite green hydrochloride. Leucomalachite green is the reduced form of MG while malachite green hydrochloride is an industrial grade $[2,3,4]$. The range of normal concentration for MG in real wastewater is around 800 ppm [5].

According to the minimum required performance limits (MRPLs) that are established by Commission Decision 2004/25/EC17, the MRPLs of MG and LMG residue in meat and seafood products is $2.0 \mu \mathrm{g} / \mathrm{kg}$ [6]. Furthermore, a report prepared by the Water Research Centre for the Department of the Environment, Transport, and the Regions of the United Kingdom recommended an annual average environmental quality standard of $500 \mathrm{ng} / \mathrm{L}$ malachite green for the protection of freshwater aquatic life, although no standards were recommended for drinking water [7].

Typically, several dye removal techniques such as biological, chemical and physical methods have been practiced for years. Biological treatments are cheaper and less time consuming, but it requires large working area and the results are unsatisfactory. Chemical methods are perceived as an effective method for dye removal. Nevertheless, the operation cost is commercially unattractive and often create a secondary pollution problems. Lastly is the physical method. Examples of popular physical methods are membrane filtration and adsorption techniques. Among these, adsorption techniques is the most popular methods due to its effectiveness, sludge free clean operation, simple design, and lower investment in both operation cost and land required for the decolourisation of dye from the industrial effluent [2, 4]. In this study, spent coffee ground was selected to investigate its potential to be utilised as bio-sorbent to treat the dye containing wastewater. Coffee has become one of the most established and recognised beverage industries globally and it is the second largest international traded commodity. Indirectly, the coffee waste generated by rapid growth of coffee industry has burden the landfill site and 
perceived as a source of contamination [8]. Recent years, several investigation on the potential of spent coffee ground as an alternative low-cost adsorbent has been carried out due to the large surface area $[9,10,11]$. The spent coffee waste was proven to be effective in removal of crystal violet and toluidine blue dye [12] and also reported that coffee residues able to remove remazol blue RN and basic blue $3 \mathrm{G}$ dye [13]. Other than that, the spent coffee rounds also can be transformed into biochar by undergo pyrolysis as to improve its adsorption performance [11]. Therefore, an alternative low cost and effective solution was developed in this study by using spent coffee grounds biochar as adsorbent to remove MG. By using potential spent coffee grounds as adsorbent might also reduce the burden of landfill site significantly.

In this study, three parameters were studied, which are adsorbent dosage $(0.02 \mathrm{~g}$ to $0.2 \mathrm{~g})$, contact time (10 minutes to 60 minutes) and $\mathrm{pH}$ (7 to 9), while the responses are percentage of $M G$ removal and its adsorption capacity $(\mathrm{mg} / \mathrm{g})$. The adsorption performance of SCGB for MG removal was studied using classical method and Response Surface Methodology (RSM). Analysis of variance (ANOVA) was also used to justify the adequacy of the models for both MG removal (\%) and adsorption capacity $(\mathrm{mg} / \mathrm{g})$. The interaction effect of parameters were studied using 3D response surface graph. Besides, diagnostic plots for predicted versus actual values of experimental responses were also examined to study the residual errors.

\subsection{METHODOLOGY}

\subsection{Preparation of Spent Coffee Grounds Biochar}

The spent coffee grounds (SCG) was collected from a certain coffee shop then washed and rinsed with water until the brown colour of the water turned clear [9]. Porcelain crucibles were filled with dried SCG and introduced into muffle furnace. The target temperature for production of biochar is $500^{\circ} \mathrm{C}$ and duration of pyrolysis process was 4 hours. The SCG biochar was grinded and sieved using sieving machine. The SCG biochar powder was collected and kept in desiccator and used for further analysis.

\subsection{Batch Adsorption Studies}

A stock solution of MG (1000 mg/L) was prepared in distilled water, and the working solutions were prepared from successive dilution of stock solution. Preliminary study revealed that $37^{\circ} \mathrm{C}$ was an optimum temperature for $M G$ removal and this was in good agreement with Rajeshkannan et al. [14] and Amaranath [15]. Moreover, the optimum agitation speed from preliminary study was at 150 rpm, this was also proven in the previous study conducted by Crini et al. [16]. The concentration of MG being determined using preliminary study that conducted to determine the basis for this study. Hence, for batch adsorption studies, the constant parameters in this study are determined, namely, initial MG concentration $(50 \mathrm{mg} / \mathrm{L})$, temperature $\left(37{ }^{\circ} \mathrm{C}\right)$, agitation speed of orbital shaker (150 rpm) and volume of MG solution (50 mL).

UV-Vis spectrophotometer Spectroquant Pharo 300 was used to measure the absorbance reading of MG solution. Malachite green (MG) was measured at $618 \mathrm{~nm}$ [5]. The percentage of MG removal was calculated using Equation 1 and the adsorption capacity of adsorbent was calculated using Equation 2 [17, 18]. The data was then inserted in Design Expert software (ver. 10) for analysis

Percentage of MG removal,

$Y(\%)=\left(\frac{C_{0}-C_{f}}{C_{0}} \times 100 \%\right)$

Where, $C_{0}$ represent initial concentration and $C_{f}$ represent final concentration of the MG solution.

Adsorption Capacity, $q_{e}(\mathrm{mg} / g)=\frac{\left(C_{e}-C_{f}\right) \times V}{m}$

Where, $V$ represents the volume of $M G$ solution in litres and $m$ represent the mass of adsorbent in the unit of gram.

Batch adsorption method was used in both classical experiment and central composite design response surface methodology (CCD-RSM) experiment. Classical experiment means to study the single parameter by varying a single factor while keeping the others at a specified value. Meanwhile, the CCD-RSM allowed determining the combine effects of variables towards the efficiency of $M G$ removal. Parameters that were studied in this study, namely, adsorbent dosage (0.02 $\mathrm{g}$ to $0.2 \mathrm{~g})$, contact time (10 $\mathrm{min}$ to $60 \mathrm{~min})$ and $\mathrm{pH}(7$ to 11$)$.

\subsection{Classical Experiments}

In order to investigate the adsorption effect caused by the parameters accurately, few constant variables were determined in this study, which are temperature $\left(37^{\circ} \mathrm{C}\right)$, agitation speed (150 rpm), initial concentration of $M G(50 \mathrm{mg} / \mathrm{L})$ and volume of $M G$ solution $(50 \mathrm{~mL})$. The classical experiments were performed by varying a single factor while keeping the others at a specified value. The effect of adsorption parameters including: adsorbent dose (0.02 $\mathrm{g}, 0.11 \mathrm{~g}$ and $0.2 \mathrm{~g})$, contact time $(10 \mathrm{~min}, 35$ min and $60 \mathrm{~min})$, and $\mathrm{pH}(7,9,11)$ on the $M G$ removal efficiency was investigated. 


\subsection{Experimental Design and Response Surface Methodology (RSM)}

The setting of CCD in Design Expert software (version 10.0), the independent variables were A (adsorbent dosage), B (contact time) and $\mathrm{C}(\mathrm{pH})$, while the response variable was \% (MG removal) and $q_{e}$ (adsorption capacity). The detailed information of each parameters with its minimum (low) level, centre and maximum (high), which are shown in Table 1. From the design, total number of experimental runs was 20 with different operating conditions. The regression model of experimental data was determined using empirical polynomial equation, the statistical significance of the model and the regression term were evaluated by analysis of variance (ANOVA).

Table 1 Real variables with their respective coded values

\begin{tabular}{lcccccc}
\hline \multirow{2}{*}{ Variable } & \multicolumn{3}{c}{ Real values } & \multicolumn{3}{c}{ Coded values } \\
\cline { 2 - 7 } & Low & Center & High & Low & Center & High \\
\hline $\begin{array}{l}\text { Adsorbent } \\
\text { dosage (g) }\end{array}$ & 0.02 & 0.11 & 0.2 & -1 & 0 & +1 \\
$\begin{array}{l}\text { Contact } \\
\text { time (min) }\end{array}$ & 10 & 35 & 60 & -1 & 0 & +1 \\
$\mathrm{pH}$ & 7 & 9 & 11 & -1 & 0 & +1 \\
\hline
\end{tabular}

\subsection{Optimisation Studies}

The optimisation studies were performed by comparing all the actual experimental results with the predicted experimental data by Design Expert software 10.0. Then, the experimental data was undergoing analysis for two experimental responses, which were percentage of MG removal and adsorption capacity. Both of the responses, then undergo a series of evaluation such as ANOVA, development of polynomial regression model equation, diagnostic plot for predicted values versus actual values. Next, the experimental data was observed and analysed using 3D surface plot that generated by Design Expert Software Version 10.0.

\subsection{RESULTS AND DISCUSSION}

\subsection{Classical Experiments}

\subsubsection{Effect of Adsorbent Dosage}

Figure 1 (a) shows the relationship between the effects of adsorbent dosage on the percentage of MG removal. Based on the results, the average percentage removal of MG showed a steady increase trend from $96.20 \%$ to $97.32 \%$ with the increase of adsorbent dosage from $0.02 \mathrm{~g}$ to $0.20 \mathrm{~g}$, respectively This can be attributed to the increased of active adsorbent site and adsorbent's surface [16, 19]. Besides, similar trend was also reported by Aadil et al. [20].
On the other hand, the adsorption capacity was found decreased dramatically from $120.25 \mathrm{mg} / \mathrm{g}$ to $22.06 \mathrm{mg} / \mathrm{g}$, and further decreased to $12.16 \mathrm{mg} / \mathrm{g}$ with the increasing amount of adsorbent dosage from $0.02 \mathrm{~g}$ to $0.20 \mathrm{~g}$ as shown in Figure 1 (b). This can be attributed to the aggregation of adsorbents molecules which lead to decrease in the total surface area and active adsorption sites of adsorbent as well as increase in diffusion path length $[21,22]$. Similar observation also has been published by Nuengmatcha et al. [23].

\subsubsection{Effect of Contact Time}

Figure 2(a) shows a significant increase for the percentage of MG removal from $81.84 \%$ to $97.07 \%$ with the increase of contact time from 10 minutes to 35 minutes, respectively. The MG removals (\%) continue to show an increasing trend with slight increase to $98.65 \%$ at 60 minutes of contact time. On the other hand, Figure 2(b) also shows the similar trend whereby the adsorption capacity was increased from $18.60 \mathrm{mg} / \mathrm{g}$ to $22.06 \mathrm{mg} / \mathrm{g}$ with increase of contact time from 10 minutes to 35 minutes respectively, and further increase to 22.42 $\mathrm{mg} / \mathrm{g}$ at 60 minutes of contact time.

Initially, the increased of dye adsorption and adsorption capacity can be attributed to the availability of large number of active adsorption sites which positioned at the surface as well as inner pores of the adsorbent particles. The diffusion rate of adsorbate particles from the bulk phase to solid adsorbent was high [21]. Therefore, an increase of dye removal percentage and adsorption capacity was observed at the time interval of 10 minutes to 35 minutes. Next, further increase of contact time only resulted in small increase of adsorbent dosage and adsorption capacity can be attributed to the limited adsorption site on adsorption surface as most of the active adsorption sites were adsorbed by the dye molecules $[16,18,24]$. 

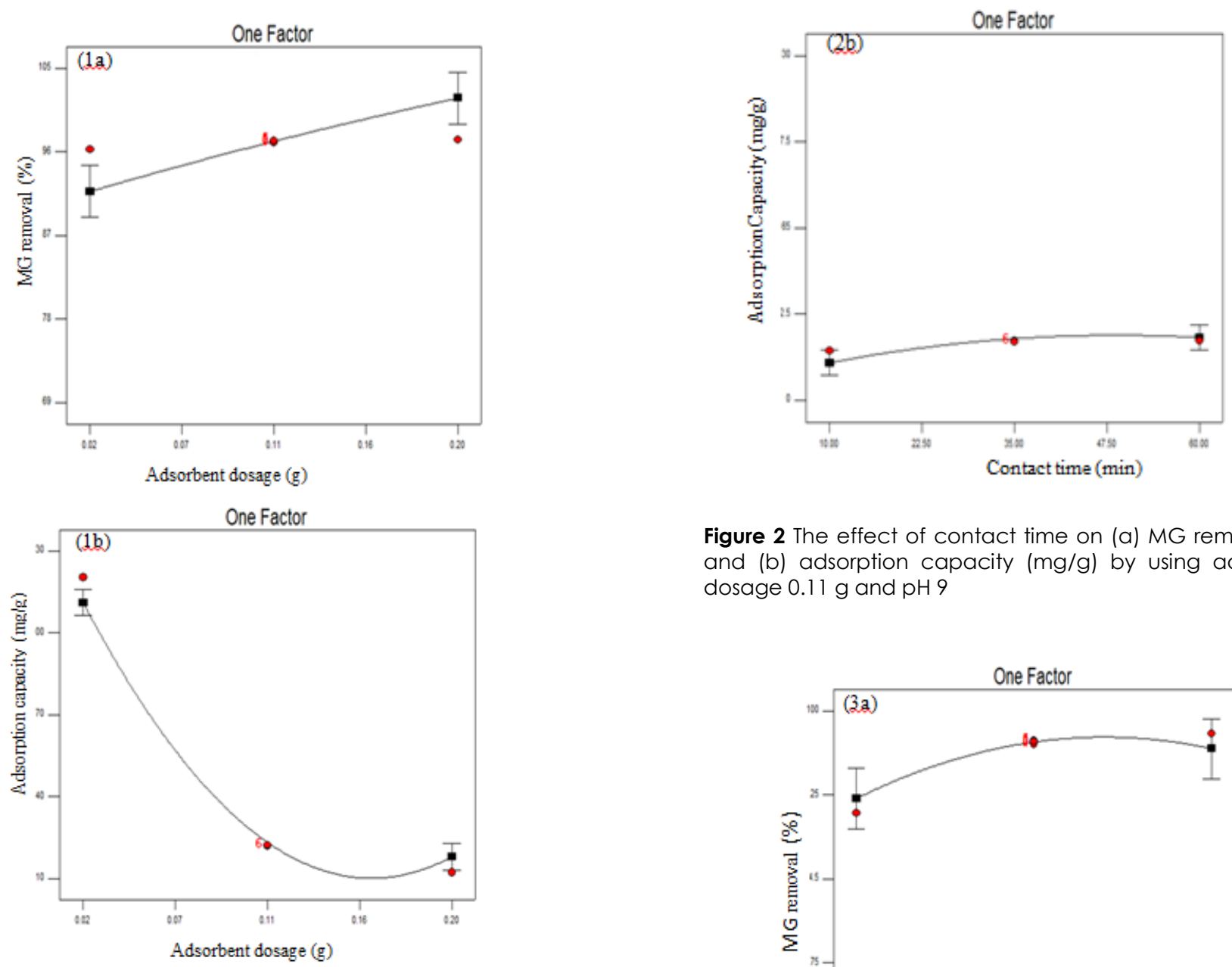

Figure 2 The effect of contact time on (a) MG removal (\%) and (b) adsorption capacity $(\mathrm{mg} / \mathrm{g}$ ) by using adsorbent dosage $0.11 \mathrm{~g}$ and $\mathrm{pH} 9$
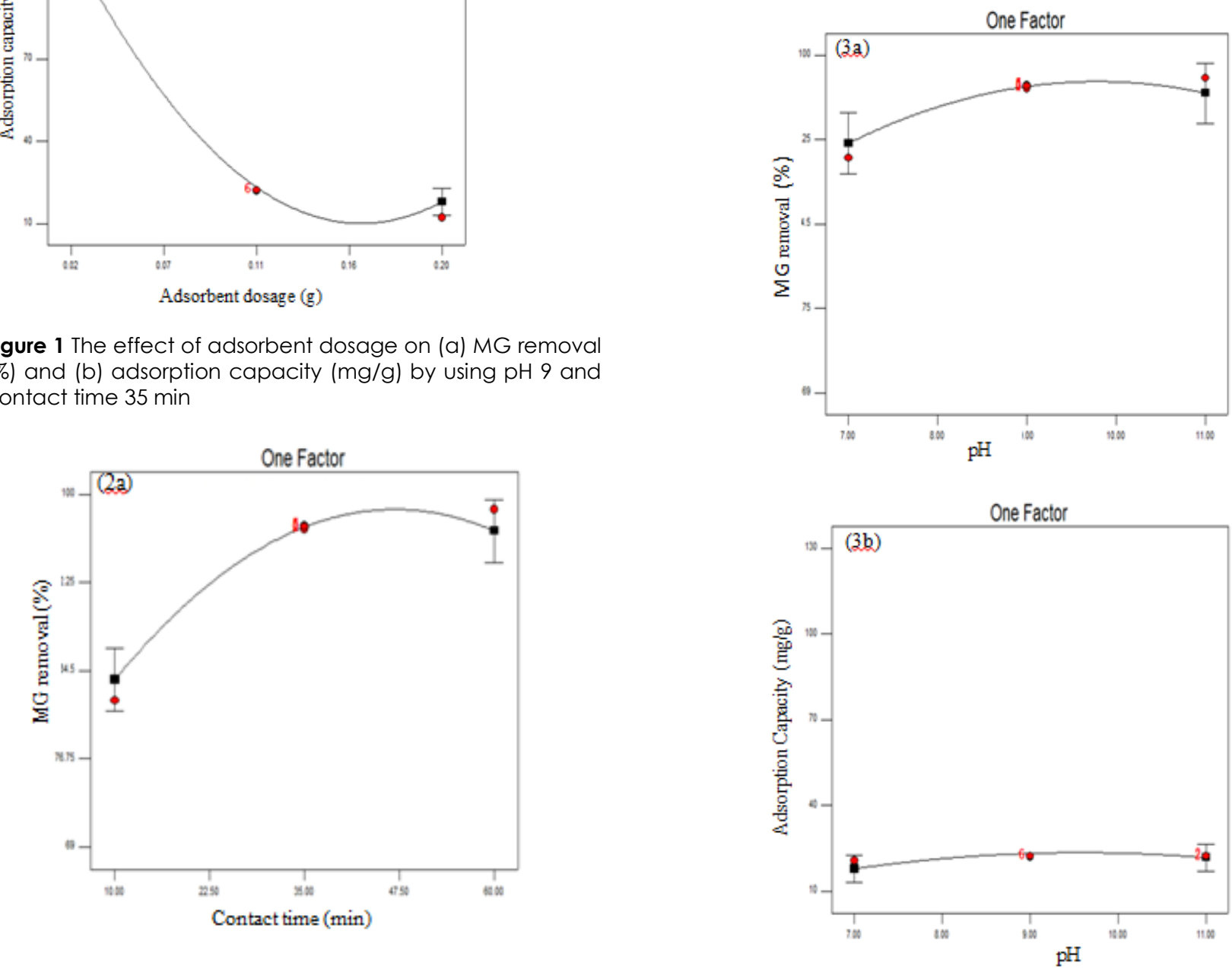

Figure 3 The effect of $\mathrm{pH}$ on (a) MG removal (\%) and (b) adsorption capacity $(\mathrm{mg} / \mathrm{g})$ by using adsorbent dosage

$0.11 \mathrm{~g}$ and contact time $35 \mathrm{~min}$

Figure 1 The effect of adsorbent dosage on (a) MG removal $(\%)$ and (b) adsorption capacity (mg/g) by using $\mathrm{pH} 9$ and contact time $35 \mathrm{~min}$ 


\subsubsection{Effect of $\mathrm{pH}$}

Figures $3(\mathrm{a})$ and $3(\mathrm{~b})$ shows the effect of $\mathrm{pH}$ on the MG removal and adsorption capacity at the $\mathrm{pH}$ of 7 , 9 and 11 , respectively. In fact, a preliminary study on the effect of $\mathrm{pH}$ on MG removal was carried out at a range of $\mathrm{pH} 2$ to $\mathrm{pH}$ 12. Briefly, $M G$ removal was low and inefficient at the acidic range of $\mathrm{pH} 2$ to $\mathrm{pH} 6$ due to presence of large amount of $\mathrm{H}^{+}$ions, which caused protonation of functional group of the adsorbent. Protonation cause the adsorption surface of adsorbent to be more positive, which create a repulsive force from preventing the positively charged MG molecules to be adsorbed on the adsorbent [25]. Therefore, pH 7 (neutral) was selected as the minimum level on the study of $\mathrm{pH}$ effect on MG removal.

At $\mathrm{pH}$ 7, MG removal was the lowest compared to $\mathrm{pH} 9$ and $\mathrm{pH} 11$. The percentage of MG removal was increased steadily from $90.54 \%$ to $97.07 \%$ with the increase of $\mathrm{pH} 7$ to $\mathrm{pH} 9$ and an equilibrium state was achieved thereafter $\mathrm{pH}$ 9. The percentage of $M G$ removal was $97.7 \%$ at $\mathrm{pH} 11$. Theoretically, $M G$ is a cationic dye and it exists in the form of positively charges ions in the solution. The effectiveness of cationic dye molecules adsorbed to adsorbent surface was largely depend on surface charge of the adsorbent, which in turn influenced by the $\mathrm{pH}$ solution. As pH 7 increased to $\mathrm{pH} 9$, the negatively charge density of adsorbent increased due to deprotonation of functional group of adsorbent. Therefore, the positively charged MG ions were more easily to be adsorbed to the negatively charged adsorbent surface due to increase of electrostatic force of attraction [26] and adsorption capacity of adsorbent [27].

\subsection{Response Surface Methodology}

In this study, the experiments were carried out at specific combination of different parameters using statistical experimental design (RSM - Design Expert Software Ver. 10.0) to determine the combined effects as well as individual effect of variables towards the efficiency of MG removal. Table 2 shows the experimental design matrix and responds value. The maximum percentage of MG removal was $98.65 \%$ with the operating conditions of $0.11 \mathrm{~g}$ of adsorbent dosage (A), 60 minutes of contact time (B) and $\mathrm{pH} 9(\mathrm{C})$. The highest adsorption capacity was $120.25 \mathrm{mg} / \mathrm{g}$ with the operating conditions of $0.02 \mathrm{~g}$ of adsorbent dosage, 35 minutes of contact time and $\mathrm{pH}$ 9. To determine the relationship between the independent variables and its corresponding response, several types of model, namely, linear, 2FI, quadratic and cubic model have been investigated. The program recommends quadratic model for MG removal (\%) with R-squared 0.95 and adjusted Rsquared 0.90 . For $M G$ adsorption capacity, the program also recommends quadratic model with $R$ squared of 0.99 and adjusted R-squared of 0.9 .
RSM generated an empirical polynomial regression model in terms of coded factors which reflects the interaction and significance of variables towards efficiency of $M G$ removal. The empirical formula for polynomial regression model in terms of coded factors for $M G$ removal (\%) and $M G$ adsorption capacity after excluding the insignificant terms are shown in Equation (3) and (4), respectively.

MG removal, $Y(\%)=97.13+5.03 \mathrm{~A}+6.54 \mathrm{~B}+2.30 \mathrm{C}+$ $2.32 A B-1.56 A C+0.52 B C-0.38 A^{2}-6.89 B^{2}-2.92 C^{2}$

Adsorption capacity, $q_{e}(\mathrm{mg} / \mathrm{g})=23.1-46.55 \mathrm{~A}+$ $4.77 B+1.95 C-5.01 A B-2.17 A C+0.43 B C+41.35 A^{2}-$ $4.35 B^{2}-3.45 C^{2}$

From the model, the positive sign in the coded equation represented that MG removal will be increased with the increase of the respective parameters. On the contrary, the negative sign indicate the negative effect towards the experimental response. Combination from the predicted data based on Equation ( 3 and 4 ) and the experimental data are given in Figures 4 (a) and (b). This figure shows the relationship between actual and predicted values of responses for MG removal by SCG biochar. From the diagnostic plot, the residuals were distributed near to the straight line and indicated that the developed quadratic model was adequate to predict the response of dye removal over the range of parameters studied. The F-test analysis of variance (ANOVA) was used to test the statistical significance of the model; whereas $\mathrm{p}$-value was used to check the significance and pattern of interaction between the experimental parameters shown in Table 3 (a) and (b). If the value of $p$-value was less than 0.05 (95\% confidence level), the model terms are considered as statistically significant [28, 17]. In contrast, values greater than 0.10 are considered as statistically insignificant.

Table 2 Experimental design matrix and response values

\begin{tabular}{llllll}
\hline Run & $\begin{array}{l}\text { Adsorbent } \\
\text { dosage, } \\
\text { (A) }\end{array}$ & $\begin{array}{l}\text { Contact } \\
\text { time, } \mathbf{m i n} \\
\text { (B) }\end{array}$ & $\begin{array}{l}\text { pH } \\
\text { (C) }\end{array}$ & $\begin{array}{l}\text { Removal } \\
\text { of } \mathbf{M G} \text { (\%) }\end{array}$ & $\begin{array}{l}\text { Adsorption } \\
\text { capacity, } \\
\mathbf{m g} / \mathbf{g}\end{array}$ \\
\hline 1 & 0.02 & 10 & 7 & 69.54 & 86.93 \\
2 & 0.20 & 10 & 7 & 89.31 & 11.16 \\
3 & 0.02 & 60 & 7 & 85.01 & 106.27 \\
4 & 0.20 & 60 & 7 & 96.05 & 12.00 \\
5 & 0.02 & 10 & 11 & 75.26 & 94.08 \\
6 & 0.20 & 10 & 11 & 89.34 & 11.16 \\
7 & 0.02 & 60 & 11 & 93.36 & 116.70 \\
8 & 0.20 & 60 & 11 & 97.60 & 12.20 \\
9 & 0.02 & 35 & 9 & 96.20 & 120.25 \\
10 & 0.20 & 35 & 9 & 97.32 & 12.16 \\
11 & 0.11 & 10 & 9 & 81.84 & 18.60 \\
12 & 0.11 & 60 & 9 & 98.65 & 22.42 \\
13 & 0.11 & 35 & 7 & 90.54 & 20.57 \\
14 & 0.11 & 35 & 11 & 97.90 & 22.25 \\
15 & 0.11 & 35 & 9 & 97.07 & 22.06 \\
16 & 0.11 & 35 & 9 & 97.19 & 22.09 \\
17 & 0.11 & 35 & 9 & 97.17 & 22.08 \\
18 & 0.11 & 35 & 9 & 96.93 & 22.03 \\
19 & 0.11 & 35 & 9 & 97.22 & 22.09 \\
20 & 0.11 & 20 & 9 & 97.15 & 22.08 \\
\hline
\end{tabular}


From Table 3(a) for MG removal (\%), Model F-value was 21.37 and $\mathrm{p}$-value was $<0.0001$ which indicated the model was significant. Table $3(\mathrm{~b})$ for $M G$ adsorption capacity $(\mathrm{mg} / \mathrm{g})$ also concluded as a significant model, which was the model $F$ value 169.33 and $p$ - value $<0.0001$. In the case of MG removal (\%), the following terms were significant with p-value less than 0.05: adsorbent dosage (A), contact time (B), $\mathrm{pH}(\mathrm{C})$, interaction effect between adsorbent dosage and contact time $(A B)$ and squared effect of contact time (B2). Moreover, adsorbent dosage (A), contact time (B), interaction effect between adsorbent dosage and contact time $(A B)$ and squared effect of adsorbent dosage $\left(A^{2}\right)$ were significant model terms in the case of $M G$ adsorption capacity $(\mathrm{mg} / \mathrm{g}$ )

Table 3 Analysis of variance (ANOVA) for response surface quadratic model

\begin{tabular}{|c|c|c|c|c|c|c|}
\hline Source & $\begin{array}{l}\text { Sum of } \\
\text { Squares }\end{array}$ & df & $\begin{array}{l}\text { Mean of } \\
\text { Square }\end{array}$ & F-value & $\begin{array}{c}p- \\
\text { value }\end{array}$ & Remarks \\
\hline \multicolumn{7}{|c|}{ (a) MG Removal (\%) } \\
\hline Model & 1221.70 & 9 & 135.74 & 21.37 & $\begin{array}{l}< \\
0.0001\end{array}$ & Significant \\
\hline $\begin{array}{l}\text { A- } \\
\text { Adsorbent } \\
\text { dosage }\end{array}$ & 252.51 & 1 & 252.51 & 39.75 & $\begin{array}{l}< \\
0.0001\end{array}$ & Significant \\
\hline $\begin{array}{l}\text { B-Contact } \\
\text { time }\end{array}$ & 427.45 & 1 & 427.45 & 67.29 & $\begin{array}{l}< \\
0.0001\end{array}$ & Significant \\
\hline C-pH & 52.95 & 1 & 52.95 & 8.34 & 0.016 & Significant \\
\hline$A B$ & 43.11 & 1 & 43.11 & 6.79 & 0.026 & Significant \\
\hline$A C$ & 19.50 & 1 & 19.50 & 3.07 & 0.110 & $\begin{array}{l}\text { Not } \\
\text { significant }\end{array}$ \\
\hline BC & 2.15 & 1 & 2.15 & 0.34 & 0.573 & $\begin{array}{l}\text { Not } \\
\text { significant }\end{array}$ \\
\hline$A^{2}$ & 0.40 & 1 & 0.40 & 0.062 & 0.808 & $\begin{array}{l}\text { Not } \\
\text { significant }\end{array}$ \\
\hline$B^{2}$ & 130.70 & 1 & 130.70 & 20.58 & 0.001 & Significant \\
\hline$C^{2}$ & 23.43 & 1 & 23.43 & 3.69 & 0.083 & $\begin{array}{l}\text { Not } \\
\text { significant }\end{array}$ \\
\hline R-squared & 0.950 & & & & & \\
\hline \multicolumn{7}{|c|}{ (b) MG Adsorption capacity (mg/g) } \\
\hline Model & 29035.40 & 9 & 3226.16 & 169.33 & $\begin{array}{l}< \\
0.0001\end{array}$ & Significant \\
\hline $\begin{array}{l}\text { A- } \\
\text { Adsorbent } \\
\text { dosage }\end{array}$ & 21673.58 & 1 & 21673.58 & 1137.60 & $\begin{array}{l}< \\
0.0001\end{array}$ & Significant \\
\hline $\begin{array}{l}\text { B-Contact } \\
\text { time }\end{array}$ & 227.11 & 1 & 227.11 & 11.92 & 0.006 & Significant \\
\hline C-pH & 37.85 & 1 & 37.85 & 1.99 & 0.189 & $\begin{array}{l}\text { Not } \\
\text { Significant }\end{array}$ \\
\hline$A B$ & 200.87 & 1 & 200.87 & 10.54 & 0.008 & Significant \\
\hline$A C$ & 37.78 & 1 & 37.78 & 1.98 & 0.189 & $\begin{array}{l}\text { Not } \\
\text { Significant }\end{array}$ \\
\hline$B C$ & 1.51 & 1 & 1.51 & 0.079 & 0.784 & $\begin{array}{l}\text { Not } \\
\text { significant }\end{array}$ \\
\hline$A^{2}$ & 4701.0 & 1 & 4701.0 & 246.7 & $\begin{array}{l}< \\
0.0001\end{array}$ & Significant \\
\hline$B^{2}$ & 52.07 & 1 & 52.07 & 2.73 & 0.129 & $\begin{array}{l}\text { Not } \\
\text { significant }\end{array}$ \\
\hline$C^{2}$ & 32.70 & 1 & 32.70 & 1.72 & 0.219 & $\begin{array}{l}\text { Not } \\
\text { significant }\end{array}$ \\
\hline R-squared & 0.993 & & & & & \\
\hline
\end{tabular}

Thus, the statistical results indicate that these models accurately predict the MG removal (\%) and MG adsorption capacity in the range of variables studied. A three-dimensional (3D) response surface graph shows in Figures 5 and 6 . These figures were obtained to examine the effect of potential relationship between the variables on the MG dye removal while keeping others variable as constant. The graphs in Figure 5 indicate that by increasing the adsorbent dosage or contact time and using $\mathrm{pH}$ at 9 to 11 , the MG removal (\%) will increase. Meanwhile, Figure 6 shows that decreasing adsorbent dosage and increasing contact time and using $\mathrm{pH}$ at 9 will increase the adsorption capacity $(\mathrm{mg} / \mathrm{g})$. These result similar with the classical experiment, study for the effect of adsorbent dosage, contact time and $\mathrm{pH}$ on MG removal (\%) and adsorption capacity $(\mathrm{mg} / \mathrm{g})$.
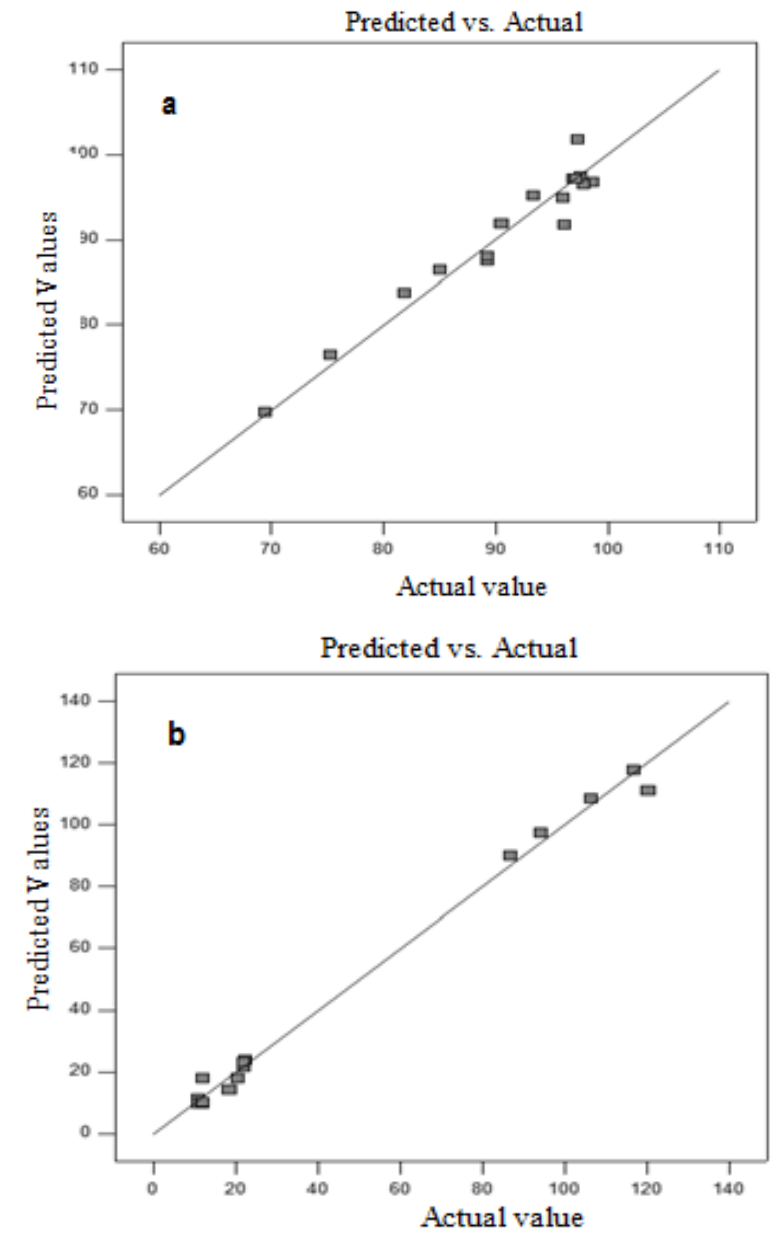

Figure 4 Predicted vs. experiment value of (a) MG removal (\%) and (b) MG adsorption capacity (mg/g)

\subsection{Process Optimisation}

From the optimisation of desirability function generated by Design Expert Software (Ver. 10), the best optimisation point for MG removal (\%) and adsorption capacity $(\mathrm{mg} / \mathrm{g}$ ) was selected based on the highest desirability function. The optimum value of process variables for MG removal are by using adsorbent dosage $0.12 \mathrm{~g}$, contact time 43.05 minutes and $\mathrm{pH}$ of 9.45 , which has up to $99.27 \%$ of $M G$ dye removal, at desirability of 1.0. The optimum value of 
process variables for adsorption capacity are by using adsorbent dosage $0.02 \mathrm{~g}$, contact time 60 minutes and $\mathrm{pH}$ 10.24, which has the adsorption capacity up to $118.01 \mathrm{mg} / \mathrm{g}$, at desirability of 0.98 . These selected conditions were within of experimental design proposed by the software.
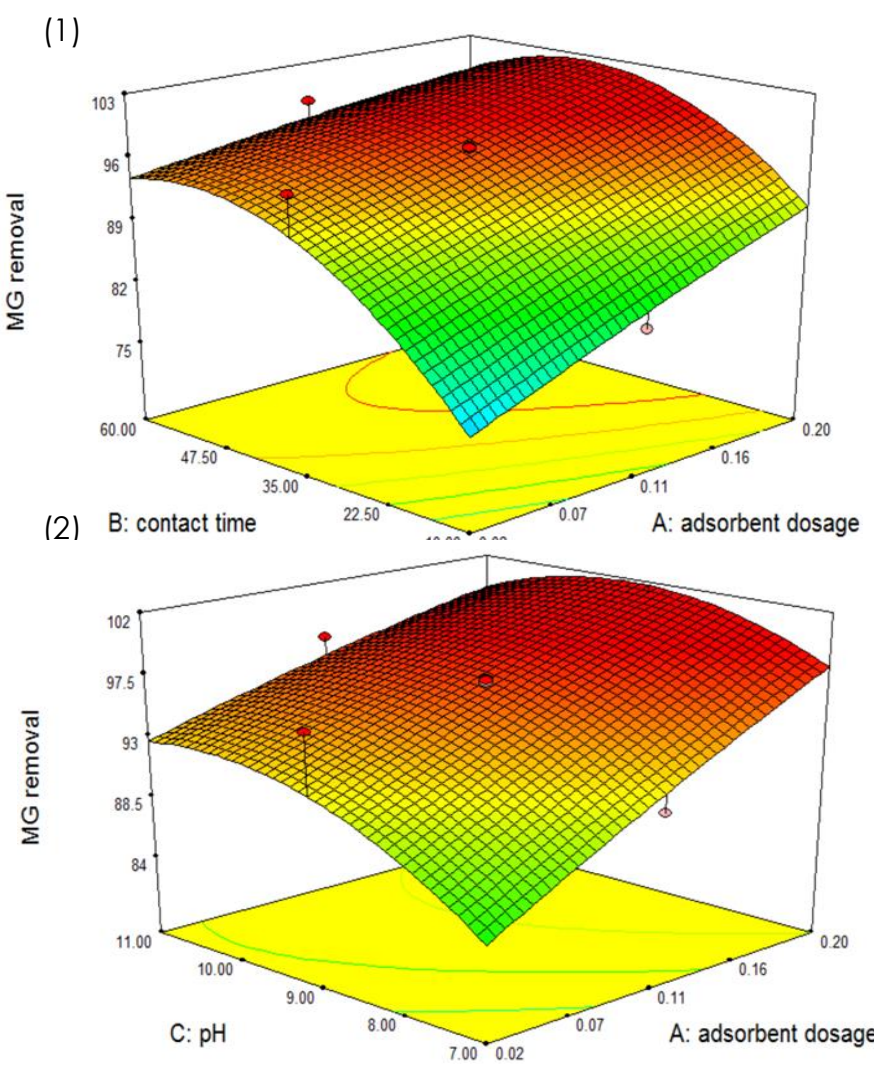

(3)

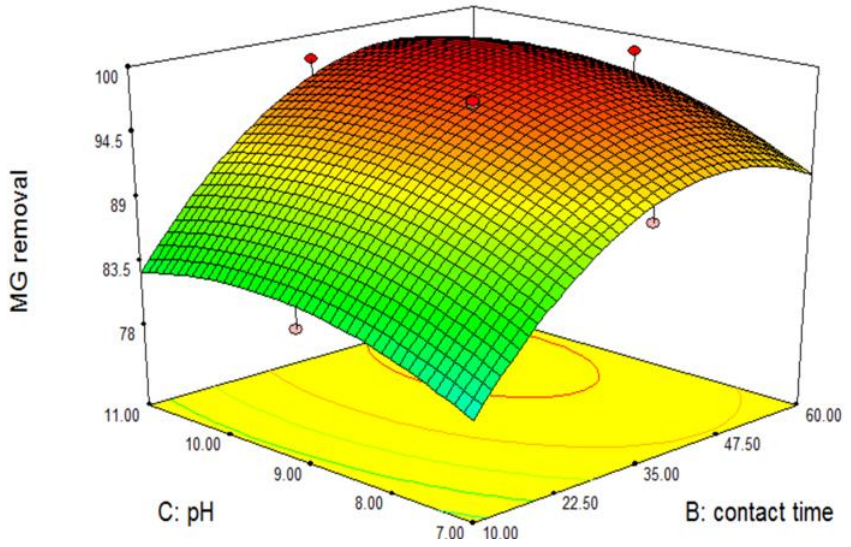

Figure 5 3D plots: (1) the effect of contact time and adsorbent dosage, (2) the effect of $\mathrm{pH}$ and adsorbent dosage and (3) the effect of $\mathrm{pH}$ and contact time on the MG removal (\%)
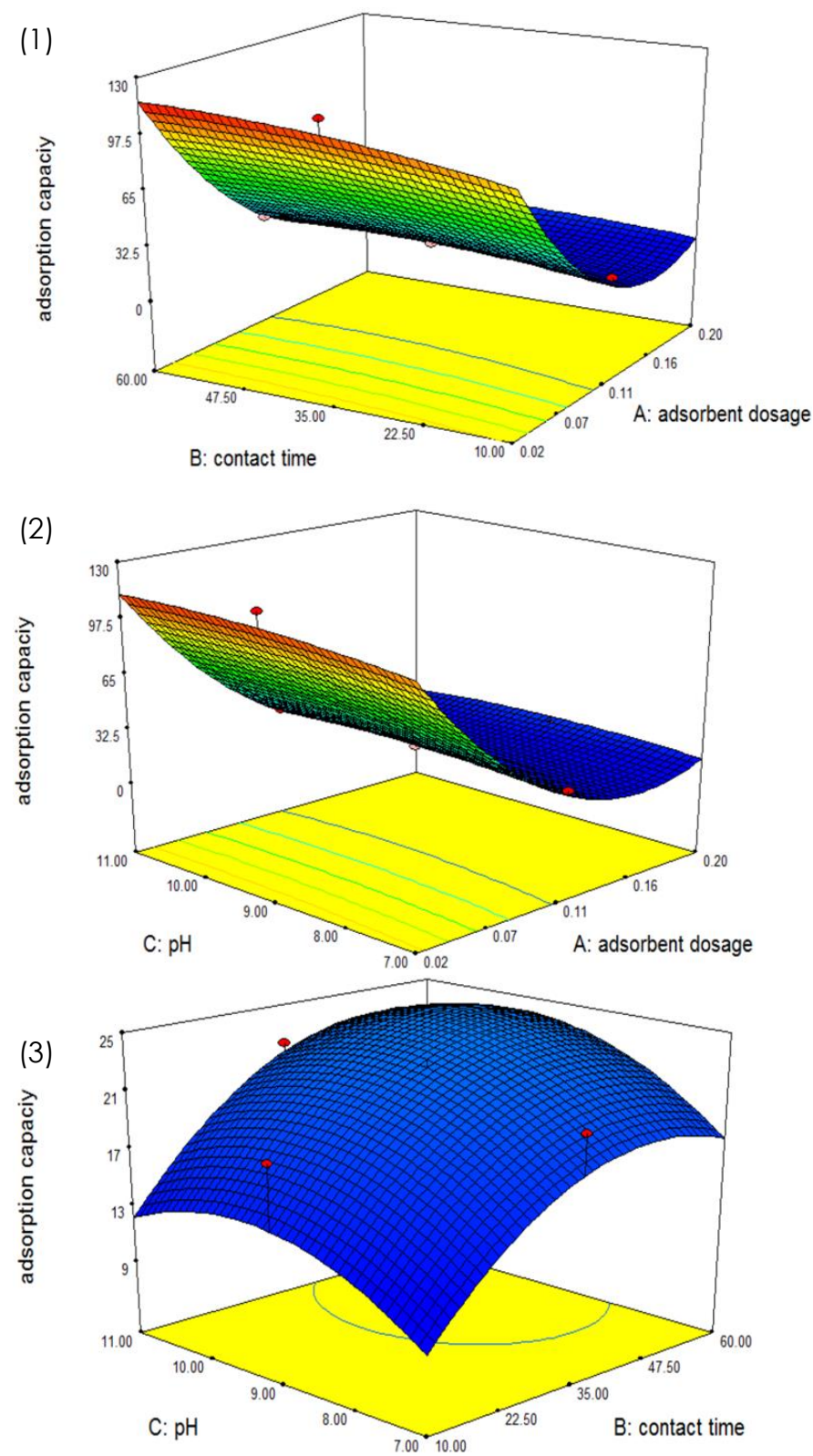

Figure 6 3D plots: (1) the effect of contact time and adsorbent dosage, (2) the effect of $\mathrm{pH}$ and adsorbent dosage and (3) the effect of $\mathrm{pH}$ and contact time on the MG adsorption capacity $(\mathrm{mg} / \mathrm{g})$

\subsection{CONCLUSION}

In this study, spent coffee ground biochar (SCGB) served as an effective low cost adsorbent in the removal of Malachite Green (MG) from the aqueous solutions. Adsorption of MG on SCG biochar was investigated by using classical and statistical methods for experimental design. Both studies show that adsorbent dosage, contact time and $\mathrm{pH}$ significantly affect the MG removal and adsorption capacity. From the predicted model generated by Design Expert Software (ver. 10), the optimum MG 
removal was $99.27 \%$ and the optimum adsorption capacity was $118.01 \mathrm{mg} / \mathrm{g}$. This indicate that from 50 $\mathrm{mg} / \mathrm{L}$ of $M G$ initial concentration, there was 0.36 $\mathrm{mg} / \mathrm{L} M G$ residue remain in the aqueous solution after treatment by using SCGB biochar. This final number do not reach the annual average environmental quality standard of malachite green (500 ng/L) by Water Reserch Canter, UK. Even so, this report proved that SCG biochar is a promising biosorbent for the removal of $M G$ from aqueous solution and to be further studied for other applications.

\section{Acknowledgement}

The authors acknowledge the financial support received in the form of grants from the Ministry of Higher Education Malaysia via Fundamental Research Grant, R/FRGS/ A1300 /01155A /003/2018 /00559.

\section{References}

[1] Adeyemo, O. K., Alarape, S. A., \& Emikpe, B. O. 2011. Reprotoxic Effect of Malachite Green on African Catfish Clarias Gariepinus (Burchell 1822). Journal of Fisheries and Aquatic Science. 6(5): 563-570.

DOI: 10.3923/jfas.2011.563.570.

[2] Rajabi, H. R., Khani, O., Shamsipur, M., \& Vatanpour, V. 2013. High-performance Pure and Fe3+-ion Doped ZnS Quantum Dots as Green Nanophotocatalysts for the Removal of Malachite Green Under UV-light Irradiation. Journal of Hazardous Materials. 250: 370-378.

DOI: https://doi.org/10.1016/j.jhazmat.2013.02.007.

[3] Srivastava, S., Sinha, R., \& Roy, D. 2004. Toxicological Effects of Malachite Green. Aquatic Toxicology. 66(3): 319-329.

DOI: https://doi.org/10.1016/j.aquatox.2003.09.008.

[4] Pointing, S. B., \& Vrijmoed, L. L. P. 2000. Decolorization of Azo and Triphenylmethane Dyes by Pycnoporus Sanguineus Producing Laccase as the Sole Phenoloxidase. World Journal of Microbiology and Biotechnology. 16(3): 317-318. DOI: https://doi.org/10.1023/A:1008959600680.

[5] Lam, K. Y., Mohammad, M., Lim, J. W., Pasupuleti, V. R., Wee, S. K., \& Kamil, R. N. M. 2015. Overview of Dyes Bearing Wastewater Treatment Methods Focusing on Adsorption Process: Precursors and Production Processes of Activated Carbon. Platform Journal of Engineering, Science and Society. 11 (1): 2-25.

URL: http://press.utp.edu.my/wpcontent/uploads/2019/07/Platform-Vol-11-No-1_.pdf.

[6] European Commission (EC). 2007. European Commission Staff Working Document on the implementation of National Residue Monitoring Plans in the Member States in 2007.

[7] Burchmore, S., and Wilkinson, M. 1993. Proposed Environmental Quality Standards for Malachite Green in Water (DWE 9026). UK Department of the Environment Transport, and the Regions Report No. 3167/2, prepared by the Water Research Centre, Marlow, Buckinghamshire, England.

[8] Kadir, A. A., Hinta, H., \& Sarani, N. A. 2015. The Utilization of Cofee Waste into Fired Clay Brick. ARPN Journal of Engineering and Applied Science. 10(15): 6280-6292. URL:

https://www.researchgate.net/profile/Noor_Sarani/public
ation/282740755_The_utilization_of_coffee_waste_into_fire d_clay_brick/links/5626172908ae4d9e5c4c8710.pdf.

[9] Mohamad M., Wannahari R., Kamal A. A. A,, Mohammad R., Zaudin N. A. C., Choong S. H \& Lim J. W. 2020. Spent Coffee Grounds Bio Char as a Low-cost Adsorbent for Methylene Blue Removal from Aqueous Solution: Optimisation Using Surface Respond Methodology. ARPN Journal of Engineering and Applied Science. 15(3): 437447. URL:

http://www.arpnjournals.org/jeas/research_papers/rp_202 0/jeas_0220_8111.pdf.

[10] Mantonanaki, A., Pellera, F. M. \& Gidarakos, E. 2015 September. Use of Biochar Generated from Spent Coffee Grounds for the Removal of Zn (II) from Aqueous Solutions. Proceedings of the 14th International Conference on Environmental Science and Technology, Rhodes, Greece. 3-5.

URL:

https://www.researchgate.net/profile/Antonia_Mantonan aki/publication/290982391_Use_of_biochar_generated_fro m_spent_coffee_grounds_for_the_removal_of_ZnIl_from_a queous_solutions/links/5750206508ae5c7e547a8a60.pdf.

[11] Chinmai, K., Hamsa, B. C., D'souza, K. D., Chandra, B. M., \& Shilpa, B. S. 2014. Feasibility Studies on Spent Coffee Grounds Biochar as an Adsorbent for Color Removal. International Journal of Application or Innovation in Engineering \& Management. 3(10): 9-13.

URL: http://www.ijaiem.org/Volume3lssue 10/IJAIEM-201410-07-2.pdf.

[12] Lafi, R., Fradj, A., Hafiane, A., \& Hameed, B. H. 2014. Coffee Waste as Potential Adsorbent for the Removal of Basic Dyes from Aqueous Solution. Korean Journal of Chemical Engineering. 31 (12): 2198-2206. DOI: https://doi.org/10.1007/s1 1814-014-0171-7.

[13] Kyzas, G. Z., Lazaridis, N. K., \& Mitropoulos, A. C. 2012 Removal of Dyes from Aqueous Solutions with Untreated Coffee Residues as Potential Low-cost Adsorbents: Equilibrium, Reuse and Thermodynamic Approach. Chemical Engineering Journal. 189-190, 148-159. DOI: https://doi.org/10.1016/j.cej.2012.02.045.

[14] Rajeshkannan, R., Rajasimman, M., \& Rajamohan, N. 2011. Decolourization of Malachite Green Using Tamarind Seed: Optimization, Isotherm and Kinetic Studies. Journal of Chemical Industry and Chemical Engineering Quarterly/CICEQ. 17(1): 67-79.

URL: $\quad$ http://scindeks.ceon.rs/article.aspx?artid=1451$93721101067 R$.

[15] Amaranath, C. 2016. Optimization of Malachite Green Decolorization Using Achromobacter Aegrifaciens by Response Surface Methodology and Central Composite Design. International Journal of Research in Engineering and Technology. 05: 312-317. DOI:10.15623/IJRET.2016.0516069.

[16] Crini, G., Peindy, H. N., Gimbert, F., \& Robert, C. 2007. Removal of $\mathrm{Cl}$ Basic Green 4 (Malachite Green) from Aqueous Solutions by Adsorption Using Cyclodextrinbased Adsorbent: Kinetic and Equilibrium Studies. Separation and Purification Technology. 53(1): 97-110. DOI: https://doi.org/10.1016/j.seppur.2006.06.018.

[17] Wannahari R., Mohamad M., Kamala A. A., \& Joanne Y. S. 2019. Removal of Malachite Green Dye by Peanut (Arachis Hypogaea) Shell Biochar: Optimisation Using Surface Respond Methodology. International Journal of Scientific \& Technology Research. 8(10): 2564- 2569.

URL: http://www.ijstr.org/paper-references.php?ref=IJSTR1019-24134.

[18] Mohamad M., Wei T. C., Mohammad R., \& Lim J. W. 2017. Optimization of Operating Parameters by Response Surface Methodology for Malachite Green Dye Removal Using Biochar Prepared from Eggshell. ARPN Journal of Engineering and Applied Science. 12(11): 3621-3633. URL: http://www.arpnjournals.org/jeas/research_papers/rp_201 7/jeas_0617_6098.pdf. 
[19] Wannahari, R., Sannasi, P., Nordin, M. F. M., \& Mukhtar, H. 2018. Sugarcane Bagasse Derived Nano Magnetic Adsorbent Composite (SCB-NMAC) for Removal of Cu 2+ from Aqueous Solution. ARPN J. Eng. Appl. Sci. 13: 1-9. URL:

http://www.arpnjournals.org/jeas/research_papers/rp_202 0/jeas_0220_8111.pdf,

[20] Aadil, A., Shahzad, M., Kashif, S., Muhammad, M., Rabia, A., \& Saba, A. 2012. Comparative Study of Adsorptive Removal of Congo Red and Brilliant Green Dyes from Water Using Peanut Shell. Middle East Journal of Scientific Research. $11(6)$ : 828-832. URL: http://www.idosi.org/mejsr/mejsrl 1 (6)12/20.pdf.

[21] Saha, P., Chowdhury, S., Gupta, S., Kumar, I., \& Kumar, R. 2010. Assessment on the Removal of Malachite Green Using Tamarind Fruit Shell as Biosorbent. CLEAN-Soil, Air, Water. 38(5-6): 437-445. DOI: https://doi.org/10.1002/clen.200900234.

[22] Garg, V. K., Gupta, R., Yadav, A. B., \& Kumar, R. 2003. Dye Removal from Aqueous Solution by Adsorption on Treated Sawdust. Bioresource Technology. 89: 121-124. DOI: http://doi.org/10.1016/S0960-8524(03)00058-0.

[23] Nuengmatcha, P., Mahachai, R., \& Chanthai, S. 2014. Thermodynamic and Kinetic Study of the Intrinsic Adsorption Capacity of Graphene Oxide for Malachite Green Removal from Aqueous Solution. Oriental Journal of Chemistry. 30(4): 1463-1474. DOI: http://dx.doi.org/10.13005/ojc/300403.
[24] Deniz, F. 2013. Adsorption Properties of Low-cost Biomaterial Derived from Prunus Amygdalus I. for Dye Removal from Water. The Science World Journal. 1-8. DOI: http://doi.org/ 10.1155/2013/961671.

[25] Ebrahimi, A., Arami, M., Bahrami, H., \& Pajootan, E. 2013. Fish Bone as a Low-cost Adsorbent for Dye Removal from Wastewater: Response Surface Methodology and Classical Method. Environmental Modeling \& Assessment. 18(6): 661-670. DOl: https://doi.org/10.1007/s10666-013-9369-z.

[26] Chowdhury, S., Mishra, R., Saha, P., \& Kushwaha, P. 2011. Adsorption Thermodynamics, Kinetics and Isosteric Heat of Adsorption of Malachite Green onto Chemically Modified Rice Husk. Desalination. 265(1-3): 159-168. DOI: https://doi.org/10.1016/j.desal.2010.07.047.

[27] Pourjavadi, A., Doulabi, M., \& Doroudian, M. 2014. Adsorption Characteristics of Malachite Green Dye onto Novel kappa-carrageenan-g-polyacrylic Acid/TiO 2-NH 2 Hydrogel Nanocomposite. Journal of the Iranian Chemical Society. 11 (4): 1057-1065. DOI: https://doi.org/10.1007/s13738-013-0374-6.

[28] Nordin, M. F. M, Manickam, Y, Shameli K, Tsuji T, Noor M. J.M. M, Shariff, A. H. M., Wannahari, R \& Nawi A. S. M. 2019. Application of Activated Carbon Derived from Durian Wastes for Improving Turbidity, Total Organic Carbon, and Dissolved Organic Carbon. Ecology, Environment, and Conservation. 25(2): 888-895.

URL:http://www.envirobiotechjournals.com/article_abstra ct. .php? aid=9665\&iid=275\&jid=3 . 